\title{
Brand Salience, Brand Association, Brand Quality, and Brand Value to Predict Brand Loyalty Among the Tourists of Mount Bromo, East Java, Indonesia
}

\author{
Stella Lamlo ${ }^{1}$, Frangky Selamat ${ }^{*}$ \\ ${ }^{1}$ Management Department, Faculty of Economics \& Business, Universitas Tarumanagara, Jakarta, Indonesia \\ *Corresponding author. Email: frangkys@fe.untar.ac.id
}

\begin{abstract}
This study aimed to determine the predictive ability of brand salience, brand association, brand quality, and brand value on brand loyalty among the tourists to visit Mount Bromo destination in East Java, Indonesia. The data in this study was collected using a survey to 100 respondents who had visited the tourist destination of Mount Bromo more than once. The results of this study indicate that brand salience, brand association, brand quality, and brand value can positively predict the tourists' brand loyalty. These results are expected to provide an overview for tourist destination managers to give full attention to the development of tourism brands which are the key to building tourist loyalty.
\end{abstract}

Keywords: Brand Salience, Brand Association, Brand Quality, Brand Value, Brand Loyalty

\section{INTRODUCTION}

Bank of Indonesia stated that tourism is an important sector and is the most effective approach in boosting Indonesia's foreign exchange due to adequate resources (human, area, diversity). In 2018, the Indonesian tourism sector was recorded as having the highest growth position, which was ranked the $9^{\text {th }}$ in the world according to The World Travel \& Tourism Council (WTTC).

However, the number of foreign tourists visiting Indonesia is lower than that of neighboring countries, such as Thailand, Malaysia, and Singapore, which in turn will make it inevitable to say that Indonesia actually fails to attract foreign tourists, despite of the outstanding travel destinations that Indonesia currently, and since so long, has. Travel destinations are important things that human beings usually use to learn new things, relax, or just for moments of being with family and friends. The destination itself is traditionally a geographical area such as a country, island, or city [1], which is a geographical area as a location that can attract tourists to stay temporarily consisting of various tourism products [2] such as a group of attractions, facilities, and services to the tourists [3].

In the perspective of destination marketing, travel destinations are designed to satisfy the travelers' needs. Therefore, the role of destination marketing is essential to explore and improve the potentials that travel destinations may have in order to create, communicate, deliver, and exchange all offers that have value for customers and by providing benefits and remaining accountable to society at large [4].

Destination marketing is maximized, if it involves brands. A brand is a symbol, a sign, an interrelated design, which aims to differentiate the products and services from competitors [5]. Furthermore, a brand is more than just a product, because it has dimensions that differentiate it from other similar products [6].

This research focuses on the travel destination called Mount Bromo that is located in East Java, Indonesia. The beauty and history within Mount Bromo make it well known globally to offer the mountain destination with various natures and cultures. The government of Indonesia has made several attempts to improve Mount Bromo in order to increase the Customer-Based Brand Equity (CBBE) of Mount Bromo and in-time achieve brand loyalty among the tourists.

The concept of "Customer-Based Brand Equity (CBBE) contributes to the progress of brand building [6]. $\mathrm{CBBE}$ is defined as "a consumer response to the marketing of the brand to create a differential effect that is owned by a brand." [7] The CBBE concept is based on the strength of a brand that lies in what is in the mind and heart of the customer. Positive CBBE resulting from good experiences will provide benefits to companies in which customers are more able to accept the product expansion from a brand, that are less sensitive to price increases, and take the initiative to find new ways to get the products from new distribution channels.

Brand equity itself is defined as "a set of assets and liabilities associated with a brand, its name, and symbol, which can increase or decrease the value provided by a product or service to the company and/ or to the company's customers." [8]

Brand equity is rooted in the greater trust that consumers place toward a brand compared to its competitors. To create strong and positive brand equity, especially for a place, destination, or city, it is very important to analyze the factors that can affect the brand equity of a tourist destination. The brand equity itself has four main 
dimensions: brand salience, brand association, brand quality, and brand value [8] [9].

Those four dimensions of brand equity play a great role in enhancing brand loyalty [10]. Previous study has found that there is a relationship between brand salience and brand loyalty, in which brand salience becomes a positive predictor of brand loyalty [11]. Besides, it is also found that brand association positively predicts brand loyalty in the context of long-haul travel, which occurs in any flight that takes longer than seven hours [11]. Therefore, it is important for the government of Indonesia to maximize the brand salience in order to improve brand loyalty from the attitude of tourists and to maximize brand association in order to maintain positive impressions during tourists' travel in Mount Bromo.

Moreover, previous research has also found that brand quality [12] and brand value [13] are positive predictors of brand loyalty. The qualities of travel destinations refer to attributes such as infrastructure, accommodation, destination hygiene, and destination safety. Therefore, the government of Indonesia has to improve the brand quality and brand value through the mentioned attributes at Mount Bromo area in order to improve brand loyalty among the tourists.

\section{LITERATURE AND HYPOTHESES}

Brand salience (in the context of destinations) is "the strength of awareness of the destination in the mind of an individual when a given travel situation is considered." [10] Brand salience can also be defined as "the awareness of the brand in the minds of consumers." [14] Furthermore, brand salience can also be defined as "the propensity of the brand to be thought of by buyers (ie "stand out" from memory) in buying situations, with the aim to be remembered for the reasons intended rather than just achieve general awareness. " [15]. So, it can be concluded that brand salience is the power of memory in individuals to remember the brand of a particular product, which is a consideration for individuals to buy the product.

One of the advantages in developing brand salience is that it affects consumers to include certain brands in providing alternatives that can be a consideration for making purchases in the future [16]. Furthermore, the strong influence of brands can influence consumer purchasing decisions to buy certain brands [17]. Also, consumer awareness of a brand can offer a familiar feeling and substantial signals that can lead to strong consumer commitment (brand loyalty) to a particular brand, which is shown in the result of previous studies revealing that brand salience is a positive predictor of tourist brand loyalty, because brand salience is recognized as one of the assets of a brand that contributes in adding value to the brand itself [10] and [14]. Based on this description, the following hypothesis can be formulated:

$\mathrm{H}_{1}$ : Brand salience is a positive predictor of tourist brand loyalty.
Brand association (in the context of destinations) is "the representative of destination image and consists of anything linked in memory to the destination that influences evaluation towards the brand." [10] Brand association can also be defined as "perceptions about a brand as reflected by the brand image held in consumers' memory." [9] Furthermore, brand association "describes anything the consumer mentally links to the brand." [8] So, it can be concluded that the brand association of a brand is the perception and mental attitude of consumers related to all things related to a certain brand image that involves thoughts, opinions, feelings, visualization, and intentions of a brand.

Brand association is a platform for differentiation, positioning, and brand extension as a basis for consumers to buy a particular brand which then creates a special reason for them to buy and use the brand [8]. Besides, brand association will create consumer dependence to process, organize, and help consumers' memory when making purchase decisions [17]. Furthermore, a strong and unique brand association will strengthen brand equity to generate consumer loyalty to the brand and create a strong competitive advantage for the company [18]. The increase in consumer loyalty which emerges from a strong and unique brand association is consistent with the results of previous researches in which brand association was found to be able to predict brand loyalty positively, because a consumer with a high brand association will produce a fast memory of all things related to a particular brand [10][18]. Based on this description, the following hypothesis can be formulated as follow:

$\mathrm{H}_{2}$ : Brand association is a positive predictor of tourist brand loyalty.

Brand quality is "customer's perception of the overall quality or superiority of a product or service concerning to its intended purpose, relative to alternatives." [8] Brand quality can also be defined as "the consumer's judgment about a product's overall excellence or superiority." [19] Furthermore, brand quality (in the context of destinations) can be defined as "perceptions of the quality of a destination's infrastructure, hospitality services, and amenities such as accommodation" [20]. So, it is concluded that brand quality is the overall consumer perception or assessment of the superiority of a product or service received that involves all elements both physically and nonphysically.

Maintaining and increasing the level of brand quality is a prerequisite for increasing the brand loyalty of a product, especially to attract the tourists to re-visit Mount Bromo [21]. Furthermore, a brand that is considered to have high quality will add consumer value to a particular brand which can encourage repeat purchases and consumer loyalty to a brand [22]. Therefore, brand quality is an essential aspect to increase brand loyalty as it is found in the result of previous studies that brand quality positively predicts brand loyalty, because brand quality refers to overall perception of a brand that can increase consumer interest to make sustainable 
purchases [10] and [22]. Based on this description, the following hypothesis can be formulated as follow:

$\mathrm{H}_{3}$ : Brand quality is a positive predictor of tourist brand loyalty.

"Brand value represents the benefits that customers believe they receive to the costs they bear." [23] Brand value can also be defined as "the consumers' overall assessment of the utility of a product based on perceptions of what is received and what is given." [18] Furthermore, brand value "represents a trade-off of salient" get and give components, "which are perceived as benefits and sacrifices, respectively" [24]. So, it can be concluded that brand value is the overall evaluation of consumers on the product / service brands they receive, and are associated with what they spend, namely in the form of sacrifices for spending a certain amount of money in order to get a certain product / service brand.
Brand value is an important element in the context of marketing study, since the concept of value has increased from the development of two fundamental dimensions of consumer behavior, namely: price and psychology [25]. Besides, the brand value construct is used to explain various domains of consumer behavior such as product choice, purchase intention, and brand [26]. Furthermore, as an important idea in the context of marketing, brand value is stated to have a significant influence on brand loyalty [26], which was also shown in the results of previous researches that brand value affects brand loyalty positively, because a consumer with a high brand value for a particular brand will feel that the value of a product / service itself is greater than the sacrifices in terms of costs. [10]. Based on this description, the following hypothesis can be formulated as follow:

$\mathrm{H}_{4}$ : Brand value is a positive predictor of tourist brand loyalty.

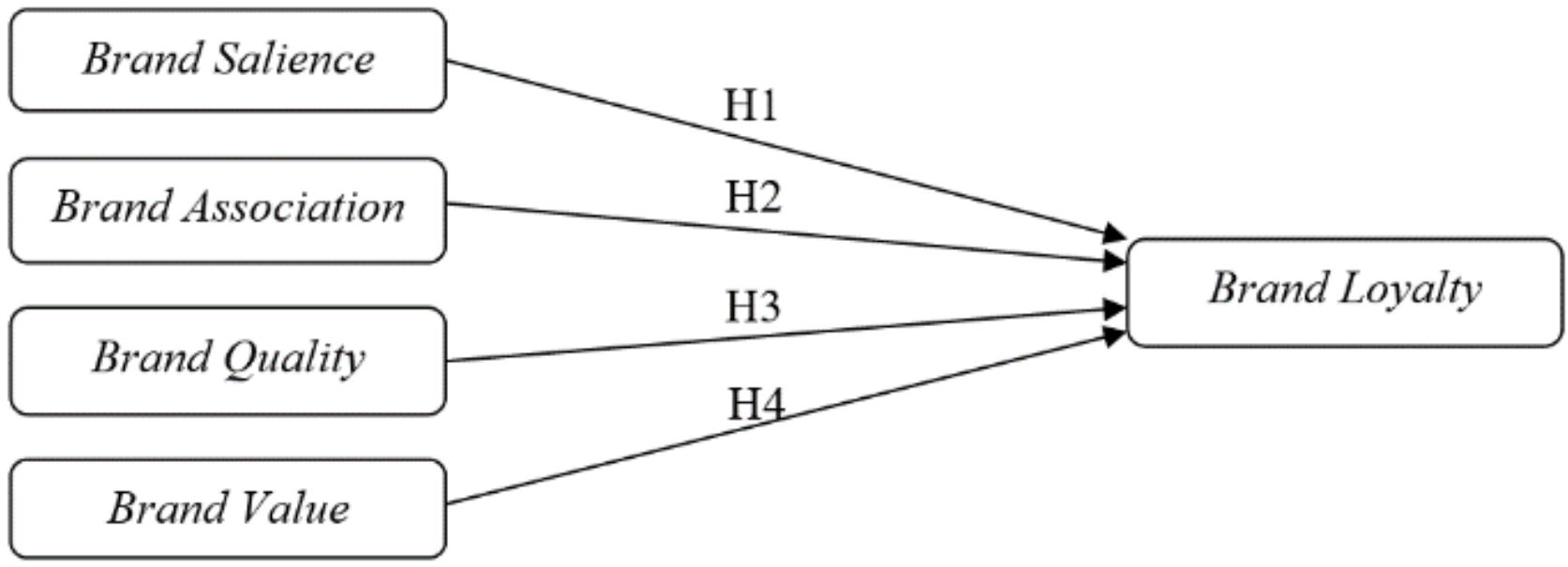

Figure 1 Research Model

\section{METHODS}

This study uses a conclusive and quantitative research design in which the data obtained is based on a representative sample. This study used a cross-sectional study. The population in this study are all people who have been to Mount Bromo. Samples were taken by using nonprobability sampling technique with purposive sampling approach based on certain criteria, namely people who know and have visited the Mount Bromo destination more than once with a sample size of 100 respondents. This research focused on people who have visited Mount Bromo at least twice, because those who have visited more tend to have more brand salience and brand association toward a brand and are more familiar with the quality and value of the brand. Thus, such characteristics are expected to provide more accuracy in predicting brand loyalty.

Among the 100 respondents, the majority are male, as many as 62 people (62\%), and based on age, the majority of respondents were aged 25-44 years, namely as many as 53 people $(53 \%)$. Furthermore, based on the marital status, the majority of respondents were not married, namely, 56 people $(56 \%)$, the majority of which earned a monthly income between IDR 20 million-IDR and 55 million-IDR were as many as 39 people (39\%), and based on the latest education, the majority were undergraduate (S1), as many as 53 people $(53 \%)$

The data was collected using a questionnaire given a score of 1-5 in the form of Likert scale, whereas the score 1 means "Very Disagree" and the score 5 means "Very Agree" to the statements in the questionnaire. Data was then analyzed using Panel Least Square - Structural Equation Modeling (PLS-SEM) with the SmartPLS version 3.3.2 software. First, the data processing was carried out on the outer-model to test its validity and reliability. The validity analysis is seen from the value of outer-loadings to be lower than 0.5 [27] and the Average Variance Extracted (AVE) value is higher than 0.5 [28].

Then, the value of cross-loadings is analyzed using the criteria for the value of outer-loadings generated by each indicator for its latent construct, which must be greater than the value of the outer-loadings for each indicator against other latent constructs [29]. Reliability analysis is seen from 
the value of the Cronbach's Alpha and composite reliability, which is at least above 0.6 to be claimed reliable [28].

Second, the data processing was carried out on the innermodel to test the hypotheses that have been generated. Before testing the hypotheses, first, the research construct was tested by looking at the $\mathrm{R}$-square $\left(\mathrm{R}^{2}\right)$ value. If the value of $\left(\mathrm{R}^{2}\right)$ is $0.99-0.75$, then the independent variable is a substantial / strong predictor. If the value of $\left(\mathrm{R}^{2}\right)$ is 0.74 0.5 , then the independent variable is a moderate predictor. For the value $\left(\mathrm{R}^{2}\right)$ between 0.49 and 0.25 , the independent variable is a weak predictor [28].

\section{Table 1 Research Constructs}

\begin{tabular}{|c|c|c|c|c|}
\hline No. & Variable & Operationalization & Code & Scale \\
\hline \multirow{6}{*}{1.} & \multirow{6}{*}{ Brand Salience $\left(\mathrm{X}_{1}\right)[10][17]$} & Mount Bromo destination has a good name and reputation. & $\mathrm{BS}_{1}$ & \multirow{6}{*}{ Interval } \\
\hline & & Mount Bromo destination is easy to remember and recall. & $\mathrm{BS}_{2}$ & \\
\hline & & Mount Bromo destination is very famous. & $\mathrm{BS}_{3}$ & \\
\hline & & Mount Bromo destination is frequently being promoted. & $\mathrm{BS}_{4}$ & \\
\hline & & Know the characteristics of Mount Bromo destination very well. & $\mathrm{BS}_{5}$ & \\
\hline & & $\begin{array}{l}\text { It is easier to recognize Mount Bromo destination than other } \\
\text { destinations. }\end{array}$ & $\mathrm{BS}_{6}$ & \\
\hline \multirow{6}{*}{2.} & \multirow{6}{*}{ Brand Association $\left(\mathrm{X}_{2}\right)[10][17]$} & Mount Bromo destination matches with personality. & $\mathrm{BA}_{1}$ & \multirow{6}{*}{ Interval } \\
\hline & & Friends recommend to visit Mount Bromo destination. & $\mathrm{BA}_{2}$ & \\
\hline & & The view of Mount Bromo destination matches with self-image. & $\mathrm{BA}_{3}$ & \\
\hline & & Visiting Mount Bromo destination reflects personality. & $\mathrm{BA}_{4}$ & \\
\hline & & Mount Bromo destination is more memorable to visit. & $\mathrm{BA}_{5}$ & \\
\hline & & Mount Bromo destination offers affordable price. & $\mathrm{BA}_{6}$ & \\
\hline \multirow{5}{*}{3.} & \multirow{5}{*}{ Brand Quality $\left(\mathrm{X}_{3}\right)[10][31]$} & Mount Bromo destination has a very good quality. & $\mathrm{BQ}_{1}$ & \multirow{5}{*}{ Interval } \\
\hline & & Mount Bromo destination has a high hygiene standard. & $\mathrm{BQ}_{2}$ & \\
\hline & & Mount Bromo destination has a high safety standard. & $\mathrm{BQ}_{3}$ & \\
\hline & & Mount Bromo destination has a high-quality infrastructure. & $\mathrm{BQ}_{4}$ & \\
\hline & & Mount Bromo destination is a top-choice destination. & $\mathrm{BQ}_{5}$ & \\
\hline \multirow{5}{*}{4.} & \multirow{5}{*}{ Brand Value $\left(\mathrm{X}_{4}\right)[10][31]$} & Mount Bromo destination has affordable price. & $\mathrm{BV}_{1}$ & \multirow{5}{*}{ Interval } \\
\hline & & $\begin{array}{l}\text { Visiting Mount Bromo destination gives more value than the } \\
\text { money spent. }\end{array}$ & $\mathrm{BV}_{2}$ & \\
\hline & & $\begin{array}{l}\text { The costs to visit Mount Bromo destination is cheaper than the } \\
\text { benefits earned. }\end{array}$ & $\mathrm{BV}_{3}$ & \\
\hline & & Mount Bromo destination is the best in terms of costs. & $\mathrm{BV}_{4}$ & \\
\hline & & $\begin{array}{l}\text { Based on the cost, time, and effort needed, Mount Bromo } \\
\text { destination is the best choice. }\end{array}$ & $\mathrm{BV}_{5}$ & \\
\hline \multirow{5}{*}{5.} & \multirow{5}{*}{ Brand Loyalty (Y) [10] [17] } & Mount Bromo destination is the best choice for vacation. & $\mathrm{BL}_{1}$ & \multirow{5}{*}{ Interval } \\
\hline & & Recommending others to visit Mount Bromo destination. & $\mathrm{BL}_{2}$ & \\
\hline & & Visiting Mount Bromo destination in the future. & $\mathrm{BL}_{3}$ & \\
\hline & & $\begin{array}{l}\text { Keep visiting Mount Bromo Destination even if the cost is } \\
\text { higher than those of other destinations. }\end{array}$ & $\mathrm{BL}_{4}$ & \\
\hline & & Visiting Mount Bromo destination becomes the first choice. & $\mathrm{BL}_{5}$ & \\
\hline
\end{tabular}

\section{RESULTS}

100 data from 100 respondents who have visited Mount Bromo destination more than once have been collected and
If the value of $\mathrm{Q}^{2}$ is higher than 0 , then this model has a strong influence. Then the value of GoF (Goodness-of-Fit), with the criteria 0.1 means "feasibility of small models", 0.25 means "feasibility of medium models", and 0.36 means "feasibility of large models" [30]. Furthermore, the hypotheses tests to see the predictions that occur between variables, can be seen from the path coefficient (original sample) generated, by using t-statistics higher than 1.645 (hypothesis is accepted) and p-values lower than 0.05 (hypothesis is accepted) [28].

The variables and the indicators used in this study are presented in Table 1 below: 
reliability analysis are shown in Table 2 and Table 3 as follows.

Table 2 Validity Analysis

\begin{tabular}{|c|c|c|c|}
\hline Indicator & Variable & Factor-Loading & AVE \\
\hline $\mathrm{BS}_{1}$ & \multirow{6}{*}{ Brand Salience } & 0.785 & \multirow{6}{*}{0.546} \\
\hline $\mathrm{BS}_{2}$ & & 0.720 & \\
\hline $\mathrm{BS}_{3}$ & & 0.683 & \\
\hline $\mathrm{BS}_{4}$ & & 0.727 & \\
\hline $\mathrm{BS}_{5}$ & & 0.580 & \\
\hline $\mathrm{BS}_{6}$ & & 0.901 & \\
\hline $\mathrm{BA}_{1}$ & \multirow{6}{*}{$\begin{array}{c}\text { Brand } \\
\text { Association }\end{array}$} & 0.885 & \multirow{6}{*}{0.93} \\
\hline $\mathrm{BA}_{2}$ & & 0.923 & \\
\hline $\mathrm{BA}_{3}$ & & 0.864 & \\
\hline $\mathrm{BA}_{4}$ & & 0.902 & \\
\hline $\mathrm{BA}_{5}$ & & 0.773 & \\
\hline $\mathrm{BA}_{6}$ & & 0.607 & \\
\hline $\mathrm{BQ}_{1}$ & \multirow{5}{*}{ Brand Quality } & 0.802 & \multirow{5}{*}{0.653} \\
\hline $\mathrm{BQ}_{2}$ & & 0.779 & \\
\hline $\mathrm{BQ}_{3}$ & & 0.789 & \\
\hline $\mathrm{BQ}_{4}$ & & 0.822 & \\
\hline $\mathrm{BQ}_{5}$ & & 0.846 & \\
\hline $\mathrm{BV}_{1}$ & \multirow{5}{*}{ Brand Value } & 0.875 & \multirow{5}{*}{0.711} \\
\hline $\mathrm{BV}_{2}$ & & 0.770 & \\
\hline $\mathrm{BV}_{3}$ & & 0.864 & \\
\hline $\mathrm{BV}_{4}$ & & 0.837 & \\
\hline $\mathrm{BV}_{5}$ & & 0.865 & \\
\hline $\mathrm{BL}_{1}$ & \multirow{5}{*}{ Brand Loyalty } & 0.914 & \multirow{5}{*}{0.682} \\
\hline $\mathrm{BL}_{2}$ & & 0.864 & \\
\hline $\mathrm{BL}_{3}$ & & 0.795 & \\
\hline $\mathrm{BL}_{4}$ & & 0.937 & \\
\hline $\mathrm{BL}_{5}$ & & 0.563 & \\
\hline
\end{tabular}

Source: Data Analysis Results

Table 2 illustrates that the values of outer-loading for each statement are higher than 0.5 , and all numbers $>0.5$ in the Average Variance Extracted (AVE) value, so that all statements and variables used in this study are declared valid. Then, the cross-loadings also pass the test, because the value generated between the indicators against the latent variable itself is greater than the value generated between the indicators against other latent variables.

Table 3 Reliability Analysis

\begin{tabular}{|l|c|c|}
\hline \multicolumn{1}{|c|}{ Variables } & $\begin{array}{c}\text { Cronbach's } \\
\text { Alpha }\end{array}$ & $\begin{array}{c}\text { Composite } \\
\text { Reliability }\end{array}$ \\
\hline Brand Salience & 0.832 & 0.876 \\
\hline Brand Association & 0.909 & 0.930 \\
\hline Brand Quality & 0.867 & 0.904 \\
\hline Brand Value & 0.898 & 0.925 \\
\hline Brand Loyalty & 0.877 & 0.912 \\
\hline
\end{tabular}

Source: Data Analysis Results
In the results of the reliability test as shown in Table 3, all figures for Cronbach's Alpha and Composite Reliability values for each statement are greater than 0.6. So, the statements used in this study are reliable.

The $\mathrm{R}$-square $\left(\mathrm{R}^{2}\right)$ value is 0.831 (strong) in the brand loyalty variable. It means that as much as $83.1 \%$ variation in the brand loyalty variable is explained by the variations in brand salience, brand association, brand quality, and brand value variables. Meanwhile, the remaining $16.9 \%$ variation in brand loyalty variable is explained by the variations in other independent variables not included in this study. The q-square value generated by this research construct is 0.562 , which means that the model has predictive relevance so that it is ideal as a research construct and the GoF value is 0.7389 , which means that the level of suitability or feasibility of this research model is strong. The test results are presented in Table 4 below:

Table 4 The Results of Hypothesis Tests

\begin{tabular}{|l|c|c|c|}
\hline \multicolumn{1}{|c|}{ Hypothesis } & t-statistics & p-values & \\
\hline $\begin{array}{l}\text { Brand Salience } \rightarrow \\
\text { Brand Loyalty }\end{array}$ & 1.773 & 0.038 & Supported \\
\hline $\begin{array}{l}\text { Brand Association } \\
\rightarrow \text { Brand Loyalty }\end{array}$ & 1.942 & 0.026 & Supported \\
\hline $\begin{array}{l}\text { Brand Quality } \rightarrow \\
\text { Brand Loyalty }\end{array}$ & 3.031 & 0.001 & Supported \\
\hline $\begin{array}{l}\text { Brand Value } \rightarrow \\
\text { Brand Loyalty }\end{array}$ & 1.816 & 0.035 & Supported \\
\hline
\end{tabular}

Source: Data Analysis Results

\section{DISCUSSION}

The statistical-test results state that the first hypothesis "Brand salience is a positive predictor of brand loyalty for tourists at Mount Bromo destination" is supported by the research data. The result of this study is in line with [10] which stated that brand salience has a positive and significant effect on brand loyalty in the context of tourist destinations. Brand Salience is recognized as one of the assets of a brand that contributes on adding value to the brand itself [14]. Therefore, brand salience is one of the factors that contribute to adding value to a brand for a particular product or service. A consumer with a high brand salience will realize that the brand is the best so that it encourages consumers to repeat consumption, recommend good things to others, and be loyal to the brand even though there are competitors with similar products or services.

The results of the statistical-tests state that the second hypothesis "Brand association is a positive predictor of brand loyalty for tourists at Mount Bromo destination" is also supported by the research data. The result of this study is in line with [10] which stated that brand association has a positive and significant effect on brand loyalty in the context of tourist destinations. Besides, it is also in line with [18] which stated that a strong and unique brand association will strengthen brand equity to generate consumer loyalty to the brand and create a strong competitive advantage for the company. Brand association is also an important element in brands in which it creates value for businesses in 
the market [7]. A consumer with a high brand association will produce a fast memory of all things related to a particular brand image that involve thoughts, opinions, feelings, visualization, and intentions of a brand so that consumers with high brand association will produce fast memories that encourage them to immediately buy or consume the product / service.

The results of the statistical tests state that the third hypothesis "Brand quality is a positive predictor of brand loyalty for tourists at Mount Bromo" is supported by research data. The result of this study is in line with [10] which stated that brand quality has a significant and positive effect on brand loyalty in the context of tourist destinations. Also, it is in line with [20] which indicated that a brand that is considered to have high quality will add consumer value to a certain brand which can encourage repeat purchases and consumer loyalty to the brand. Brand quality is a dimension of brand equity that also affects the value of a brand. Brand quality refers to the overall perception of the quality and superiority of a product / service that can increase consumer interest to make sustainable purchases.

The results of the statistical tests state that the fourth hypothesis "Brand value is a positive predictor of brand loyalty for tourists at Mount Bromo destination" is also supported by research data. This result is in line with [10] which stated that brand value has a significant and positive effect on brand loyalty in the context of tourist destinations. Also, it is in line with [32] which stated that brand value is positively related to the increased consumer satisfaction and loyalty to a brand. Brand value refers to consumers' assessment of the gap between perceived benefits and costs [33]. A consumer with high brand value for a particular product / service will feel that the value of the product / service itself is greater than the sacrifices in terms of costs, and others that they incur so that it will make consumers feel worth it for the product / service, that triggers repeat purchases and recommends good things about the product or service to others.

\section{CONCLUSION AND LIMITATION}

Brand salience, brand association, brand quality, and brand value, each of which is a positive predictor of tourist brand loyalty to visit the Mount Bromo destination. The implication is that destination marketers should pay attention to these four variables inn order to predict brand loyalty. The limitation of this study is that the sample size is limited and does not fully represent the population of tourists visiting Mount Bromo.

\section{REFERENCES}

[1] Hall, C. Michael (2008). Tourism planning, Policies, Processes and Relationships. Second Edition. Harlow: Prentice Hall.

[2] Tuohino, A., \& Konu, H. (2014). Local stakeholders' views about destination management:
Who are leading tourism development? Tourism Review of AIEST - International Association of Scientific Experts in Tourism, 69(3), 202-215. http://dx/doi.org/10.1108/TR-06-2013-0033

[3] Kim, A. K., \& Brown, G. (2012). Understanding the relationships between perceived travel experiences, overall satisfaction, and destination loyalty. Anatolia, 23(3), 328-347. https://doi.org/10.1080/13032917.2012.696272

[4] Gundlach, Gregory T., \& Wilkie, William L. (2009). The American Marketing Association's new definition of marketing: perspective and commentary on the 2007 revision. Journal of Public Policy \& Marketing, 28(2), 259-264. https://doi.org/10.1509/jppm.28.2.259

[5] Kotler, P. \& Keller, K. L. (2016). Marketing Management, $15^{\text {th }} e d$. Essex: Pearson Education, Inc.

[6] Keller, K. L. (2008). Strategic brand management: building, measuring, and managing brand equity. Third Edition. New Jersey: Pearson Prentice Hall, Inc.

[7] Keller, K. L. (2003). Brand synthesis: The multidimensionality of brand knowledge. Journal of consumer research, 29(4), 595-600. https://doi.org/10.1086/346254

[8] Aaker, D. A. (1991). Managing Brand Equity: Capitalizing on The Value of a Brand Name. New York: The Free Press, Macmilla.

[9] Keller, K. L. (1993). Conceptualizing, measuring, and managing consumer-based brand equity. Journal of Marketing, 57(1), 1-22.

https://doi.org/10.1177/002224299305700101

[10] Bianchi, C., Pike, S., \& Lings, I. (2014). Investigating attitudes towards three South American destinations in an emerging long haul market using a model of consumer-based brand equity

(CBBE). Tourism Management, 42, 215-223. https://doi.org/10.1016/j.tourman.2013.11.014.

[11] Boo, S., Busser, J. \& Baloglu, S. (2009). A model of customer-based brand equity and its application to multiple destinations. Tourism Management, 30(2), 219-231. https://doi.org/10.1016/j.tourman.2008.06.03

[12] Buhalis, D. (2000). Marketing the competitive destination of the future. Tourism Management, 21(1), 97-116. https://doi.org/10.1016/S0261-5177(99)00095- 
[13] Heskett, J. L., Sasser, W. E. J. \& Schlesinger, L. A. (1997). The service profit chain: How leading companies link profit and growth to loyalty, satisfaction, and value. New York: The Free Press.

[14] Aaker, D. A. (1996). Measuring brand equity across products and markets. California Management Review, 38(3), 102-120.

http://dx.doi.org/10.2307/41165845

[15] Romaniuk, J. \& Sharp, B. (2004). Conceptualizing and measuring brand salience. Marketing Theory, 4(4), 327-342. https://doi.org/10.1177/1470593104047643

[16] Keller, K. L. (2013). Strategic brand management: building measuring, and managing brand equity. (4th ed.). England: Pearson Education Ltd.

[17] Oppong, P. K., \& Phiri, M. A. (2018). Impact of brand awareness and association on loyalty: the role of equity in plant medicine market in Kumasi, Ghana. African Journal of Business and Economic Research, 13(2), 163-181. https://doi.org/10.31920/1750-4562/2018/v13n2a8

[18] Chen, A. C-H. (2001). Using free association to examine the relationship between the characteristics of brand association and brand equity. Journal of Product and Brand Management, 10(7), 439-457.

https://doi.org/10.1108/10610420110410559

[19] Zeithaml, V. A. (1988). Consumer perceptions of price, quality, and value: a means-end model and synthesis of evidence. Journal of Marketing, 52(3), 222. https://doi.org/10.1177/002224298805200302

[20] Pike, S. and C. Bianchi. (2013). Destination brand equity for Australia: Testing a model of CBBE in short haul and long-haul markets. Journal of Hospitality and Tourism Research, 20(10), 1-21. https://doi.org/10.1177/10966348013491604

[21] Manthiou, A., Kang, J., dan Schrier, T. (2014). A visitor-based brand equity perspective: The case of a public festival. Tourism Review of AIEST International Association of Scientific Experts in Tourism, 69(4), 264-283. https://doi.org/10.1108/TR04-2014-0016

[22] Low, G.S., \& Lamb, C.W. (2000). The measurement and dimensionality of brand associations. Journal of Product \& Brand Management, 9(6), 350368. https://doi.org/10.1108/10610420010356966

[23] McDougall, G. H. G., \& Levesque, T. (2000). Customer satisfaction with services: putting perceived value into the equation. Journal of Services
Marketing. 14(5), 392-

410. https://doi.org/10.1108/08876040010340937

[24] Chen, Z., \& Dubinsky, A. J. (2003). A conceptual model of perceived customer value in e-commerce: A preliminary investigation. Psychology and Marketing, 20(4), 323-347. https://doi.org/10.1002mar.10076

[25] Gallarza, M.G. \& Saura, Gil I. (2006). Value dimensions, perceived value, satisfaction and loyalty: an investigation of university students' travel behavior. Tourism Management, 27(3), 437-452. https://doi.org/10.1016/j.tourman.2004.12.002

[26] Hapsari, R. (2018). Creating educational theme park visitor loyalty: the role of experience-based satisfaction, image, and value. Tourism and hospitality management, 24(2), 359-274.

https://doi.org/10.20867/thm.24.2.7

[27] Ghozali, Imam. (2015). Structural equation modeling, metode alternatif dengan Partial Least Square (PLS). Edisi 4. Semarang: Badan Penerbit Universitas Diponegoro.

[28] Hair Jr, J. F., Black, W. C., Babin, B. J., \& Anderson, R. E. 2011. Multivariate data analysis 7th Edition. New Jersey: Pearson Prentice Hall.

[29] Garson, G. D. (2016). Partial least squares: regression \& structural equation models. North Carolina: Statistical Associates Publishing.

[30] Wetzels, M., Odekerken-Schroder, G., \& Oppen, C. (2009). Using PLS Path modelling for assessing hierarchical construct models: guidelines and empirical illustration. Assessing Hierarchical Construct Models. 33(1), 177-195. https://doi.org/10.2307/20650284

[31] Su, J. (2016). Examining the relationships among the brand equity dimensions: Empirical evidence from fast fashion. Asia Pacific Journal of Marketing and Logistics, 28(3), 464-480.

https://doi.org/10.1108/APJML-01-2015-0004

[32] Heskett, J. L., Sasser, W. E. J., \& Schlesinger, L. A. (1997). The service profit chain: How leading companies link profit and growth to loyalty, satisfaction, and value. New York: The Free Press.

[33] Patterson, P.G.P. \& Spreng, R.A. (1997). Modeling the relationship between perceived value, satisfaction and repurchase intentions in a business-tobusiness, services context: an empirical examination. International Journal of Service Industry Management. 8(5), 414-434.

https://doi.org/10.1108/09564239710189835 